\title{
17. PLATINUM GROUP ELEMENT (PGE) CONCENTRATIONS IN A SHEETED DIKE COMPLEX AND GEOCHEMICAL CHANGES DURING ALTERATION OF THE LOWERMOST PART OF A 2-KM-THICK OCEANIC CRUST, HOLE 504B
}

\author{
M.P. Gorton, ${ }^{2}$ E.S. Schandl, ${ }^{2}$ and A.J. Naldrett ${ }^{2}$
}

\begin{abstract}
Primary chemical heterogeneity in the sheeted dike complex in Deep Sea Drilling Project Hole 504B makes these rocks unsuitable for conventional mass balance calculations in determining element mobility associated with hydrothermal alteration. Due to the original heterogeneity and variable degrees of fractionation in the dikes, an appropriate reference sample on which calculations can be based is difficult to find. Therefore, the use of incompatible element ratios is developed to evaluate geochemical changes during alteration(s). For example, on $\mathrm{a} \mathrm{Zr} / \mathrm{Yb}-\mathrm{La} / \mathrm{Yb}$ plot, scatter along a straight line suggests tapping of a variably depleted mantle source and deviation from the line suggests element mobility (gain or loss). Using this method, our data indicates that the hydrothermal evolution of the sheeted dike complex was accompanied by significant loss of $\mathrm{Cu}, \mathrm{Zn}$, and $\mathrm{Ti}$ and some loss of $\mathrm{La}$.

The sheeted dike complex has low platinum group element (PGE) concentrations and steep PGE patterns, typical of mid-ocean ridge basalts (MORBs) on the global scale. We propose that the unusual PGE patterns of MORBs cannot be entirely generated by a partial melting and sulfide segregation model; instead, these patterns in part must have been inherited from their mantle source. The Au data show no evidence for mobilization during hydrothermal alteration of the dikes.
\end{abstract}

\section{INTRODUCTION}

The sheeted dike complex in Hole 504B was penetrated to a record depth of 2000.4 mbsf during Ocean Drilling Program Leg 140. Hole 504B is located in the Panama Basin, $200 \mathrm{~km}$ south of the Costa Rica rift zone (Fig. 1). The 5.9-m.y.-old ocean crust includes a $571.5 \mathrm{~m}$ section of volcanic rocks consisting of pillow lavas and thin flows, a 209-m transition zone consisting of pillow lavas, thin flows, and dikes, and a massive 566.5-m sheeted dike complex (Dick, Erzinger, Stokking, et al., 1992).

We investigate here the geochemical evolution of the dikes during hydrothermal/metasomatic alteration in the lowermost $350 \mathrm{~m}$ of the sheeted dike complex and determine the concentration of platinum group elements (PGE) in the unaltered and altered dike rocks. Our objectives are (1) to evaluate the use of conventional mass balance calculations in predicting trace and rare earth element (REE) mobility associated with seafloor metamorphism and/or hydrothermal alteration at $2 \mathrm{~km}$ depth below seafloor and (2) to characterize the PGE in the sheeted dikes and compare their concentration to MORB on a global scale.

\section{PREVIOUS WORK}

Previous geochemical studies have demonstrated that the basalts in Hole 504B are strongly depleted in incompatible elements ( $\mathrm{Ti}$, $\mathrm{Zr}, \mathrm{Nb}$, and REE) and have very low $\mathrm{Zr} / \mathrm{Y}$ and $\mathrm{La} / \mathrm{Sm}$ ratios (Autio and Rhodes, 1983; Marsh et al., 1983; Hubberten et al., 1983; Emmermann, 1985; Tual et al., 1985). Their low incompatible element concentrations suggest multistage melting of a mid-ocean-ridge source (Autio et al., 1989). The igneous geochemistry of the upper part of the sheeted dike complex has been studied in detail by Autio et al.

\footnotetext{
'Erzinger, J., Becker, K., Dick, H.J,B., and Stokking, L.B. (Eds.), 1995. Proc. ODP, Sci. Results, 137/140: College Station, TX (Ocean Drilling Program).

${ }^{2}$ Department of Geological Sciences, University of Toronto, Toronto, Canada M5S
}

(1989). Based on the similarities in major and trace element concentrations between the dikes and the overlying pillow basalts and flows, they concluded that the dikes represent a feeder system to the pillows.

The geochemistry of hydrothermally altered basalts in Hole 504B has been discussed in detail by Honnorez et al. (1983), Alt et al. (1986, 1989) and Alt and Emmermann (1985). Mass balance calculations by Alt and Emmermann (1985) indicate significant mobility of some elements in the basalt, losses in $\mathrm{SiO}_{2}, \mathrm{CaO}$, and $\mathrm{TiO}_{2}$ and gains in $\mathrm{MnO}$, $\mathrm{Na}_{2} \mathrm{O}, \mathrm{CO}_{2}, \mathrm{H}_{2} \mathrm{O}$, and some $\mathrm{MgO}$ occurred during alteration processes, as well as a limited amount of light rare earth element (LREE) and Eu mobility.

\section{ANALYTICAL TECHNIQUES}

Ten representative samples were analyzed for major and selected trace elements by X-ray fluorescence at the X-Ray Assay Laboratories, Toronto. Fused beads were used for major elements, and pressed powder pellets for trace elements.

The rare earth elements (REE), Hf, $\mathrm{Ta}$, Th, and $\mathrm{Cr}$ were determined by Instrumental Neutron Activation Analysis (INAA) at the University of Toronto, using the techniques of Stix and Gorton (1992) and the SLOWPOKE reactor. Sample weights were increased by a factor of two and counting times by a factor of three to improve precision.

The PGE were determined in duplicate by fire assay preconcentration, followed by INAA. Because of the very low concentrations in MORB, these determinations are difficult. These problems were compounded in this study because of the small sample size available ( $15 \mathrm{~g}$ per duplicate). For this reason a modified technique using small sulfide beads (Asif and Parry, 1989) was used. The concentrations in the blanks were: $\mathrm{Au}=0.18 \mathrm{ppb}, \mathrm{Pt}=0.3 \mathrm{ppb}$, and $\mathrm{Ir}=0.013 \mathrm{ppb}$. Agreement between duplicates was relatively poor, with about a third of the samples disagreeing by more than a factor of two. Au was also determined on the whole-rock powder by INAA, and, although results ranged from $64 \%$ to $117 \%$ of the fire assay data, no systematic difference was detected.

Primary and secondary mineralogy of rocks G1-G10 was determined by point-counting, and thin-section descriptions of the 10 samples are presented in the appendix. 


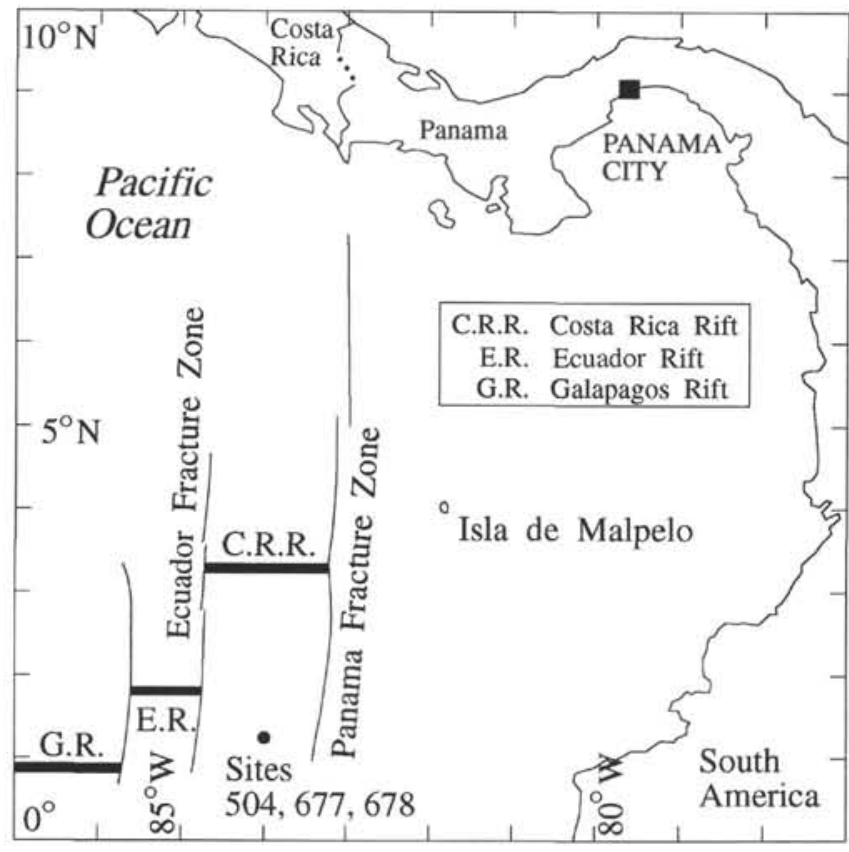

Figure 1. Location map of Hole 504B.

\section{PLATINUM GROUP ELEMENT AND REE GEOCHEMISTRY OF THE DIKES}

\section{Platinum Group Elements}

Platinum group element (PGE) concentrations of the five samples are shown in Table 1. Although 10 samples were analyzed, because of the low PGE concentrations, only five rocks gave reliable results. These five samples were normalized to the mantle values of Barnes et al. (1988) and plotted in Figure 2. There is some spread in Figure 2 , but because of the difficulty of determining the PGE at these low concentrations, the differences between samples are not considered to be significant. Figure 2 shows very steep PGE patterns with rather low concentrations, which are typical of PGE patterns from MORBs on the global scale (Hertogen et al., 1980; Crocket, 1990).

An interesting feature of Figure 2 is the lack of scatter in the Au data, especially in G-2, which has $67 \%$ alteration. This contrasts with most MORB and altered and metamorphosed mafic rocks from the terrestrial environment where Au data is commonly disturbed.

\section{Rare Earth Elements}

Rare earth element (REE) concentrations in the 10 rocks analyzed are shown in Table 2; chondrite normalized data are plotted on Figure 3.

The dikes are strongly depleted in light REE (LREE) and their $\mathrm{La} / \mathrm{Yb}$ ratios are in the range of $0.28-0.46$. These values are comparable to REE concentrations in the overlying basalts as reported in previous studies (Tual et al., 1985; Alt and Emmermann, 1985). The small range in the overall concentration of the REE (Fig. 3 ) is probably due mostly to differences in their degree of fractionation. Some of the rocks, such as G-2, 6, 7, and 8, have been extensively altered, and it will be shown later that LREE were mobilized in some of these (though this is not evident on Fig. 3). Chondrite normalized values are, by convention, plotted on a logarithmic scale, and thus, a small degree of REE mobility is not readily observed on such diagrams. The strongly LREE-depleted character of these rocks cannot be attributed to either alteration or fractionation, and must reflect depletion in the mantle source region.
Table 1. Platinum group elements, $\mathrm{Cu}$ and $\mathrm{Ni}$ in diabases, Leg 140.

\begin{tabular}{|c|c|c|c|c|c|}
\hline Core, section: & $193 R-1$ & $194 \mathrm{R}-1$ & $199 \mathrm{R}-1$ & 199R-1 & 200R-2 \\
\hline Interval $(\mathrm{cm})$ : & $0-3$ & $91-93$ & $78-80$ & $110-114$ & $49-52$ \\
\hline Depth (mbsf): & 1674.6 & 1681.3 & 1720.2 & 1720.5 & 1730.6 \\
\hline Sample number: & G-I & G-2 & G-3 & G-4 & G-5 \\
\hline Ir (ppb) & 0.027 & 0.013 & 0.010 & 0.050 & 0.001 \\
\hline $\mathrm{Pt}$ & 0.90 & 1.40 & nd & 1.70 & 0.20 \\
\hline $\mathrm{Au}$ & 1.6 & 2.1 & 3.2 & 4.4 & 3.6 \\
\hline $\mathrm{Cu}(\mathrm{ppm})$ & 62 & 28 & 74 & 72 & 65 \\
\hline $\mathrm{Ni}$ & 89.9 & 126 & 162 & 182 & 190 \\
\hline
\end{tabular}

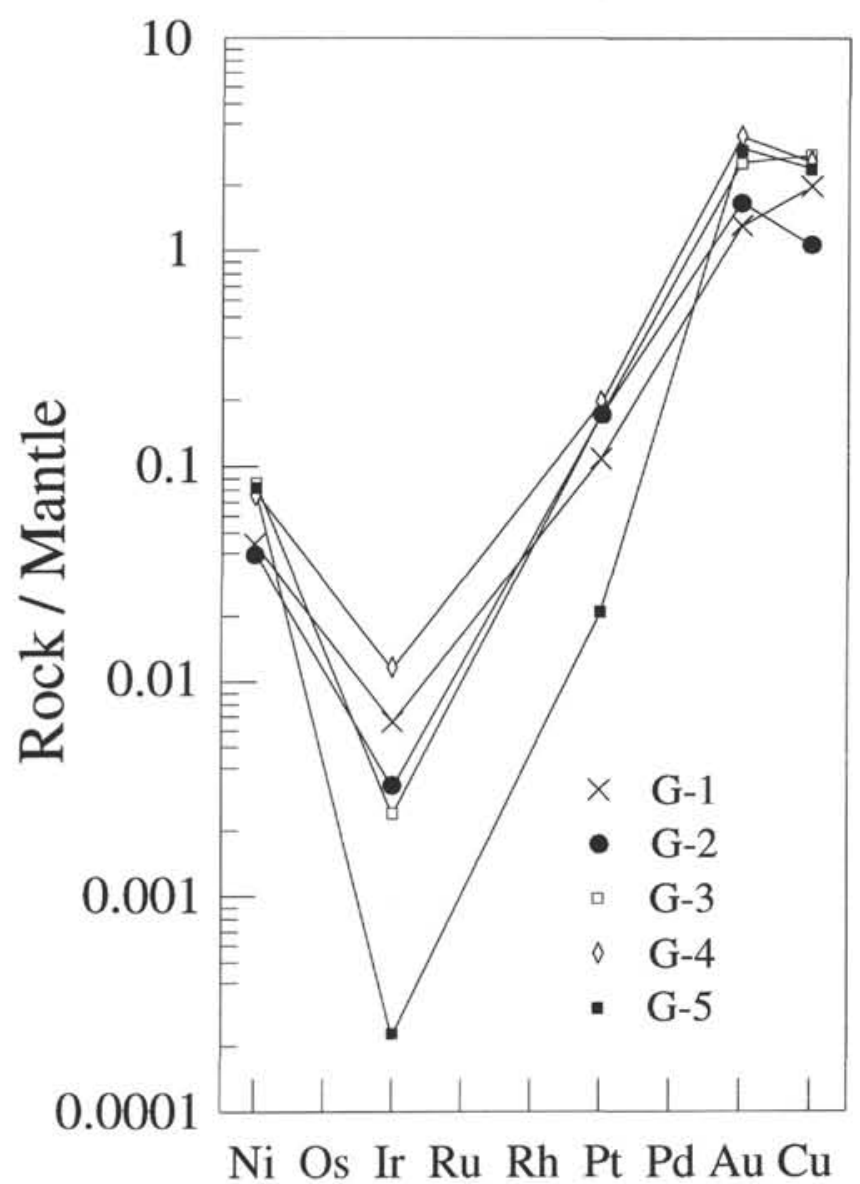

Figure 2. Mantle-normalized plot of platinum group elements (PGE) from the sheeted dikes, Hole 504B, Leg 140.

\section{GEOCHEMICAL CHANGES DURING ALTERATION PROCESSES}

The primary objective of this study was to determine the extent of element mobility associated with hydrothermal/metasomatic alteration of the sheeted dike complex and to estimate if seawater/dike interaction at $2 \mathrm{~km}$ depth could possibly have contributed to the enrichment and/ or depletion of specific elements higher in the stratigraphy. Within this study, we evaluate the use of conventional mass balance calculations in the petrogenetically inhomogeneous dikes. The following section demonstrates the results obtained with such method.

\section{Mass Balance Calculations: Gresens' Method}

A suite of eight rocks was selected for the study to determine the chemical changes associated with alteration of the lowermost $350 \mathrm{~m}$ 
Table 2. Chemical analyses of diabases, Hole 504B, Legs 137/140.

\begin{tabular}{|c|c|c|c|c|c|c|c|c|c|c|}
\hline $\begin{array}{l}\text { Core, section: } \\
\text { Interval }(\mathrm{cm}): \\
\text { Depth (mbsf): } \\
\text { Sample number: }\end{array}$ & $\begin{array}{c}193 R-1 \\
0-3 \\
1674.6 \\
G-1\end{array}$ & $\begin{array}{c}194 R-1 \\
91-93 \\
1681.3 \\
\text { G-2 }\end{array}$ & $\begin{array}{c}\text { 199R-1 } \\
78-80 \\
1720.2 \\
\text { G-3 }\end{array}$ & $\begin{array}{c}199 R-1 \\
110-114 \\
1720.5 \\
G-4\end{array}$ & $\begin{array}{c}200 \mathrm{R}-2 \\
49-52 \\
1730.6 \\
\text { G-5 }\end{array}$ & $\begin{array}{c}205 R-1 \\
18-20 \\
1757.3 \\
\text { G-6 }\end{array}$ & $\begin{array}{c}214 R-1 \\
21-22 \\
1818.9 \\
\text { G-7 }\end{array}$ & $\begin{array}{c}229 \mathrm{R}-1 \\
54-56 \\
1944.0 \\
\mathrm{G}-8\end{array}$ & $\begin{array}{c}173 R-1 \\
24-27 \\
1571.0 \\
\text { G-9 }\end{array}$ & $\begin{array}{c}236 \mathrm{R}-1 \\
76-79 \\
1981.5 \\
\mathrm{G}-10\end{array}$ \\
\hline $\begin{array}{l}\mathrm{SiO}_{2} \\
\mathrm{TiO}_{2} \\
\mathrm{Al}_{2} \mathrm{O}_{3} \\
\mathrm{Fe}_{2} \mathrm{O}_{3}^{*} \\
\mathrm{MnO}^{*} \\
\mathrm{MgO} \\
\mathrm{CaO} \\
\mathrm{Na}_{2} \mathrm{O} \\
\mathrm{K}_{2} \mathrm{O} \\
\mathrm{P}_{2} \mathrm{O}_{5} \\
\mathrm{LOI}^{-} \\
\mathrm{Total} \\
\mathrm{Mg} \text { no. } \\
\text { s.g." } \\
\text { \% alteration*** }\end{array}$ & $\begin{array}{r}50.50 \\
1.05 \\
14.30 \\
11.50 \\
0.19 \\
7.77 \\
12.70 \\
1.58 \\
0.02 \\
0.08 \\
0.80 \\
100.49 \\
59.8 \\
3.041 \\
18\end{array}$ & $\begin{array}{r}49.40 \\
0.86 \\
15.10 \\
9.90 \\
0.18 \\
8.16 \\
12.80 \\
2.00 \\
0.04 \\
0.07 \\
1.55 \\
100.06 \\
64.5 \\
2.908 \\
67\end{array}$ & $\begin{array}{c}49.10 \\
0.77 \\
16.00 \\
9.28 \\
0.16 \\
9.40 \\
13.30 \\
1.58 \\
<0.01 \\
0.06 \\
1.00 \\
100.65 \\
69.0 \\
3.001 \\
7\end{array}$ & $\begin{array}{c}48.80 \\
0.76 \\
16.10 \\
9.06 \\
0.16 \\
9.08 \\
13.60 \\
1.57 \\
0.01 \\
0.06 \\
0.90 \\
100.10 \\
68.8 \\
3.022 \\
13\end{array}$ & $\begin{array}{c}48.70 \\
0.77 \\
15.80 \\
9.24 \\
0.16 \\
9.55 \\
13.70 \\
1.53 \\
0.03 \\
0.06 \\
0.95 \\
100.49 \\
69.5 \\
3.009 \\
10\end{array}$ & $\begin{array}{r}48.70 \\
0.91 \\
15.20 \\
10.30 \\
0.17 \\
8.75 \\
13.60 \\
1.57 \\
0.03 \\
0.09 \\
1.15 \\
100.47 \\
65.1 \\
3.000 \\
72\end{array}$ & $\begin{array}{c}48.80 \\
0.64 \\
15.60 \\
10.10 \\
0.14 \\
9.33 \\
12.10 \\
1.67 \\
0.03 \\
0.06 \\
2.05 \\
100.52 \\
67.0 \\
2.897 \\
82\end{array}$ & $\begin{array}{c}49.90 \\
0.91 \\
14.50 \\
10.40 \\
0.17 \\
8.65 \\
13.40 \\
1.64 \\
0.04 \\
0.07 \\
0.70 \\
100.38 \\
64.7 \\
2.949 \\
60\end{array}$ & $\begin{array}{c}50.1 \\
0.85 \\
15.2 \\
10.2 \\
0.17 \\
7.91 \\
13.2 \\
1.5 \\
0.03 \\
0.07 \\
0.8 \\
100.03 \\
63.1 \\
\text { nd } \\
8\end{array}$ & $\begin{array}{c}49 \\
0.61 \\
16.8 \\
8.57 \\
0.14 \\
8.33 \\
13.5 \\
1.7 \\
0.05 \\
0.05 \\
1.35 \\
100.1 \\
68.1 \\
\text { nd } \\
13\end{array}$ \\
\hline $\begin{array}{l}\mathrm{Sc}(\mathrm{ppm}) \\
\mathrm{Cr} \\
\mathrm{Co} \\
\mathrm{Ni} \\
\mathrm{Cu} \\
\mathrm{Zn} \\
\mathrm{Rb} \\
\mathrm{Sr} \\
\mathrm{Zr} \\
\mathrm{Hf} \\
\mathrm{Ta} \\
\mathrm{Th}\end{array}$ & $\begin{array}{c}45.6 \\
237 \\
44.4 \\
89.8 \\
62 \\
84.6 \\
<2 \\
43 \\
59 \\
1.37 \\
0.05 \\
0.07\end{array}$ & $\begin{array}{c}44.9 \\
277 \\
40.2 \\
126 \\
28 \\
57.4 \\
<2 \\
53 \\
48 \\
1.14 \\
0.00 \\
0.00\end{array}$ & $\begin{array}{c}38.9 \\
420 \\
43.4 \\
162 \\
74 \\
66 \\
3 \\
63 \\
50 \\
1.09 \\
0.03 \\
0.00\end{array}$ & $\begin{array}{c}39.1 \\
456 \\
43.2 \\
182 \\
72 \\
65.9 \\
5 \\
64 \\
50 \\
0.99 \\
0.00 \\
0.00\end{array}$ & $\begin{array}{c}37.7 \\
435 \\
42.4 \\
190 \\
65 \\
64.3 \\
5 \\
64 \\
50 \\
0.93 \\
0.00 \\
0.00\end{array}$ & $\begin{array}{c}41.5 \\
354 \\
41.7 \\
151 \\
4 \\
85 \\
2 \\
70 \\
62 \\
1.37 \\
0.03 \\
0.00\end{array}$ & $\begin{array}{c}37.7 \\
485 \\
44.9 \\
147 \\
<2 \\
41.2 \\
4 \\
51 \\
43 \\
0.83 \\
0.03 \\
0.08\end{array}$ & $\begin{array}{l}45.2 \\
420 \\
41.8 \\
88.8 \\
<2 \\
27.9 \\
<2 \\
55 \\
56 \\
1.34 \\
0.00 \\
0.00\end{array}$ & $\begin{array}{c}42.4 \\
336 \\
41.6 \\
91.5 \\
62 \\
33.4 \\
4 \\
47 \\
50 \\
1.13 \\
0.02 \\
0.00\end{array}$ & $\begin{array}{c}36.9 \\
428 \\
38.2 \\
122 \\
20 \\
20.4 \\
<2 \\
60 \\
34 \\
0.78 \\
0.00 \\
0.00\end{array}$ \\
\hline $\begin{array}{l}\mathrm{La} \\
\mathrm{Ce} \\
\mathrm{Nd} \\
\mathrm{Sm} \\
\mathrm{Eu} \\
\mathrm{Tb} \\
\mathrm{Yb} \\
\mathrm{Lu} \\
\mathrm{La} / \mathrm{Yb}\end{array}$ & $\begin{array}{l}1.13 \\
4.34 \\
4.63 \\
2.17 \\
0.82 \\
0.62 \\
3.24 \\
0.48 \\
0.35\end{array}$ & $\begin{array}{l}0.88 \\
3.40 \\
3.78 \\
1.77 \\
0.70 \\
0.49 \\
2.66 \\
0.39 \\
0.33\end{array}$ & $\begin{array}{l}0.93 \\
3.87 \\
3.71 \\
1.66 \\
0.62 \\
0.48 \\
2.13 \\
0.34 \\
0.43\end{array}$ & $\begin{array}{l}0.99 \\
3.40 \\
3.28 \\
1.66 \\
0.60 \\
0.44 \\
2.14 \\
0.34 \\
0.46\end{array}$ & $\begin{array}{l}0.93 \\
3.74 \\
3.16 \\
1.50 \\
0.63 \\
0.46 \\
2.09 \\
0.30 \\
0.44\end{array}$ & $\begin{array}{l}1.02 \\
4.36 \\
4.81 \\
2.08 \\
0.80 \\
0.56 \\
2.77 \\
0.42 \\
0.37\end{array}$ & $\begin{array}{l}0.58 \\
2.74 \\
2.55 \\
1.30 \\
0.62 \\
0.38 \\
2.07 \\
0.31 \\
0.28\end{array}$ & $\begin{array}{l}1.13 \\
4.17 \\
3.88 \\
1.87 \\
0.74 \\
0.54 \\
2.70 \\
0.39 \\
0.42\end{array}$ & $\begin{array}{l}0.84 \\
3.09 \\
4.41 \\
1.75 \\
0.64 \\
0.50 \\
2.63 \\
0.39 \\
0.32\end{array}$ & $\begin{array}{l}0.62 \\
2.31 \\
3.08 \\
1.25 \\
0.46 \\
0.31 \\
1.67 \\
0.25 \\
0.37\end{array}$ \\
\hline
\end{tabular}

Notes: $*$ = total Fe; $* *=$ density; ${ }^{* * *}=\%$ secondary minerals determined by point-counting; nd = not determined.

of the sheeted dike complex. This suite of rocks includes relatively unaltered and extensively altered samples. To calculate the gain and loss of various elements that accompanied the recrystallization of primary minerals to secondary assemblages, we used the method of Gresens (1967). This method requires that the specific gravity of the parent rock $(g A)$ and product rock $(g B)$ be known, as well as the chemical composition of both $A$ and $B$. To solve the equation, it is essential to know either the behavior of one component $\left(x_{n}\right)$ or the volume factor $\left(f_{v}\right)$. Then, by using this volume factor, the gain and losses of various components can be calculated with the equation:

$$
100 f_{v} \frac{(g B)}{g A} c_{n}^{B}-c_{n}{ }^{A}=x_{n}
$$

(Gresens, 1967)

where $x_{n}$ is the component to be calculated; $A$ is the parent, $B$ is the product; $c_{n} B$ is the weight fraction of an element in the rock; $g$ is the specific gravity of the rock; and 100 is the sum of the elements in the rocks.

The eight rocks used in the mass balance calculations were selected from the interval $1676.4-1944.0 \mathrm{mbsf}$. One of the least altered samples, G-1, was used to represent the parent rock in the calculations, and the others (altered to various degrees) represent the products. Although some elements such as $\mathrm{Ti}, \mathrm{Ni}, \mathrm{Cr}, \mathrm{Zr}$, and $\mathrm{Al}$ are usually considered to be immobile during alteration processes and could be used in calculating the $f_{v}$, it is difficult to obtain homogeneous samples with comparable concentrations of the immobile elements when the sample sizes are only a few $\mathrm{cm}^{3}$. For example, the concentration of $\mathrm{Cr}$ and $\mathrm{Ni}$ in the Leg 140 rocks varies between 164 and $450 \mathrm{ppm}$ and 80 and $189 \mathrm{ppm}$, respectively (Dick, Erzinger, Stokking, et al., 1992). This variation may be due to the uneven distribution of small chromite grains and the presence of some millerite (Alt et al., 1989) in the rocks, or it may be due to varying degrees of fractionation. In addition, localized mobility of Ti was previously reported in amphibole-rich alteration patches by Alt et al. (1989). Then, based on petrographic observations and on the apparently immobile behavior of $\mathrm{Al}$, it was concluded that significant volume change did not occur during the alteration of the dikes. Subsequently, a volume factor of 1 was used in the calculations, and results were converted into percent changes. The results obtained by this method are shown in Figure 4.

According to these calculations, most major, trace, and rare earth elements were mobilized during the hydrothermal/metasomatic alteration of the dikes. $\mathrm{Na}_{2} \mathrm{O}, \mathrm{SiO}_{2}$, and $\mathrm{CaO}$ were the least mobile, whereas $\mathrm{Cr}, \mathrm{Ni}, \mathrm{Cu}, \mathrm{Hf}$, and the REE were the most mobile elements. Figure 4 shows a significant increase in $\mathrm{Cr}, \mathrm{Ni}$, and $\mathrm{Mg}$; significant decrease in $\mathrm{Hf}, \mathrm{REE}, \mathrm{Ti}, \mathrm{Zr}$, and $\mathrm{Cu}$; and up to $20 \%$ decrease in $\mathrm{Fe}$ and $\mathrm{Sc}$ in all of the rocks.

It is apparent that these results obtained by Gresens' mass balance calculations are geologically unreasonable. $\mathrm{Na}_{2} \mathrm{O}$ and $\mathrm{CaO}$ are considered to be among the most mobile elements during seawater-rock interaction (Humphris and Thompson, 1978; Seyfried and Bischoff, 1981), whereas $\mathrm{Cr}, \mathrm{Ni}, \mathrm{Hf}$ and the REE remain relatively immobile (Allan and Gorton, 1992). We propose that these results do not reflect element mobility during hydrothermal alteration, but rather are the consequence of geochemical heterogeneity in the rocks due to differences in magma source and in degree of fractionation. As the success of Gresens' calculations (and also of other types of mass balance calculations) is based on the assumption that the parent rock is the unaltered equivalent of the altered product, it must be demonstrated that both the altered and unaltered rocks come from a chemically homogeneous source. While this is possible to demonstrate in the overlying basalts where individual flows are relatively homogeneous (Tual et al., 1985), it is more difficult in the dikes that represent multiple pulses of magma. In the following section we will examine 


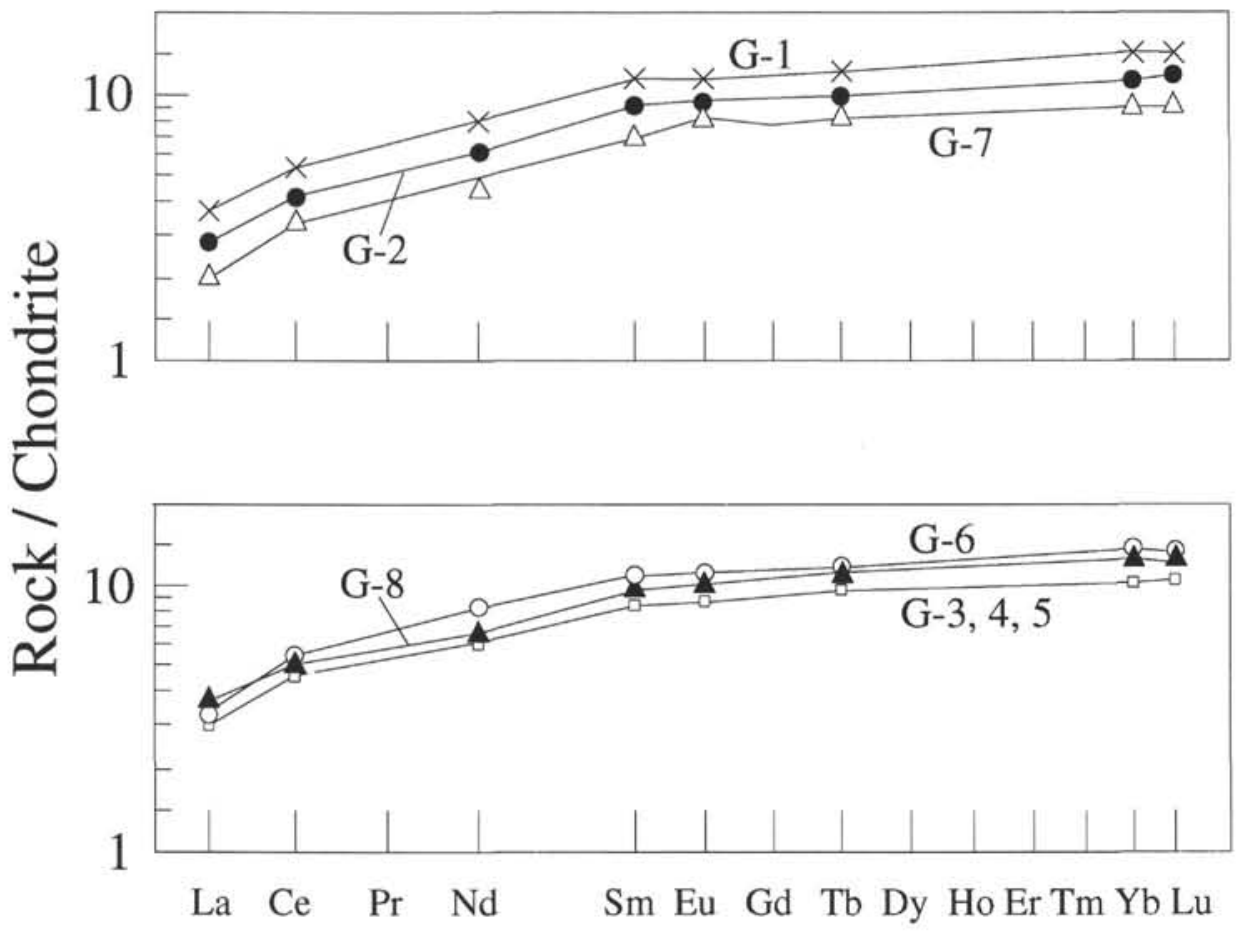

Figure 3. Chondrite-normalized REE concentrations in the sheeted dikes, Hole 504B, Leg 140.

the behavior of some elements during igneous processes, to demonstrate the extent of heterogeneity due to fractionation and show the implications of this for errors in calculating element enrichment/ depletion in the altered rocks.

The weak link in the use of calculations such as Gresens' is the selection of a suitable unaltered reference. Careful evaluation of our data reveals two different problems, each of which compromises this selection and, thus, to some degree invalidates these calculations.

1. Our data show that $\mathrm{Mg}$ numbers in the diabase range from 60 to 70 . This is in agreement with the analyses obtained on Leg 140 from the lowermost $350 \mathrm{~m}$ of the sheeted dike complex (Dick, Erzinger, Stokking, et al., 1992). These values indicate that the dikes have undergone shallow level fractionation, which would principally have involved olivine and plagioclase. Thus, samples such as our reference $\mathrm{G}-1$, which have the lowest $\mathrm{Mg}$ number (59.8) also have the lowest $\mathrm{Al}_{2} \mathrm{O}_{3}$ and $\mathrm{Sr}$ contents, as they are the most fractionated and have suffered some plagioclase removal. This essentially invalidates the use of $\mathrm{Al}_{2} \mathrm{O}_{3}$ as an immobile element, unless the altered rocks have undergone the same degree and type of fractionation.

2. As incompatible elements become enriched during fractionation, rocks that suffered similar degrees of fractionation should show similar enrichments. This is confirmed by the fact that Samples G-3, G-4, and G-5 (10\%-15\% altered), which were selected within a 5-m interval, and which have comparable $\mathrm{Mg}$ numbers, all have similar $\mathrm{Zr}$ contents $(50 \mathrm{ppm})$. However, G-10 (18\% altered), which also has a similar Mg number, has only $34 \mathrm{ppm} \mathrm{Zr}$, which is $30 \%$ lower than the other three. This problem is illustrated on $\mathrm{ar} / \mathrm{Yb}$ vs. La/ $\mathrm{Yb}$ plot (Fig. 5). Because all three elements are incompatible during fractionation, the ratios should not vary and a suite of variably fractionated but cogenetic rocks should plot as a single point on the diagram. Clearly this is not the case, indicating that the degree of enrichment of incompatible elements in the dikes is also controlled by variations in the chemistry of the mantle source. Tual et al. (1985) came to a similar conclusion for the overlying basalts. This makes it much more difficult to select a suitable unaltered reference sample for mass balance calculations, and along with variations in the degree of fractionation, explains why Gresens' calculations failed.

\section{Estimating Element Mobility in the Heterogeneous Dikes, Hole 504B}

Despite the difficulties described above, it is still possible to identify some effects that can be attributed to alteration. This can be achieved by relying on elements such as $\mathrm{Ni}$ and $\mathrm{Cr}$, which are relatively insensitive to degree of mantle source depletion, or on incompatible element ratios (such as Fig. 5), which are insensitive to the degree of fractionation.

Thus, in Figure 5 the general trend could be attributed to the correlation between $\mathrm{La}$ and $\mathrm{Zr}$, which can be explained by the tapping of a variably depleted mantle source, or mixing of magmas from two sources. G-6 and especially G-7 are significantly displaced from this trend, and although they could be interpreted in terms of a third mantle source, the fact that they are the two most altered samples ( $72 \%$ and $82 \%$, respectively) suggests that alteration is a more plausible explanation. Alteration could cause displacement from this trend only by (1) gain of $\mathrm{Zr}$ relative to $\mathrm{Yb}$, or (2) loss of La relative to $\mathrm{Yb}$. As $\mathrm{Zr}$ is highly immobile, whereas La is considered to be the most mobile REE, Figure 5 provides good evidence for loss of La from these two samples.

$\mathrm{Cu}$ is the most mobile element in the lowermost part of the sheeted dike complex. The extent of $\mathrm{Cu}$ depletion in the rock appears to parallel the extent of alteration. A plot of $\mathrm{Cu} / \mathrm{Ni}$ ratios vs. $\mathrm{Mg}$ numbers was constructed using data from the least altered samples to determine the igneous trend of $\mathrm{Cu}$ (Fig. 6). Then, using the trend from the diagram, we calculated the expected $\mathrm{Cu}$ values for the altered rocks. Table 3 shows that the $\mathrm{Cu}$ loss from the altered diabase ranges between $40 \%$ and $100 \%$.

A similar approach was used to evaluate $\mathrm{Zn}$ depletion; results are included in Table 3 . These results confirm a previously noted trend of Zn depletion with depth (Dick, Erzinger, Stokking, et al., 1992). Note that although we have reported data on a limited number of samples, the same trends can be found in the larger dataset of the Leg 140 Initial Reports (Dick, Erzinger, Stokking, et al., 1992).

Evaluation of mobility among the major elements is difficult because almost all of them are likely to be modified by fractionation, and some, such as $\mathrm{TiO}_{2}$, will also be influenced by variable depletion of the 


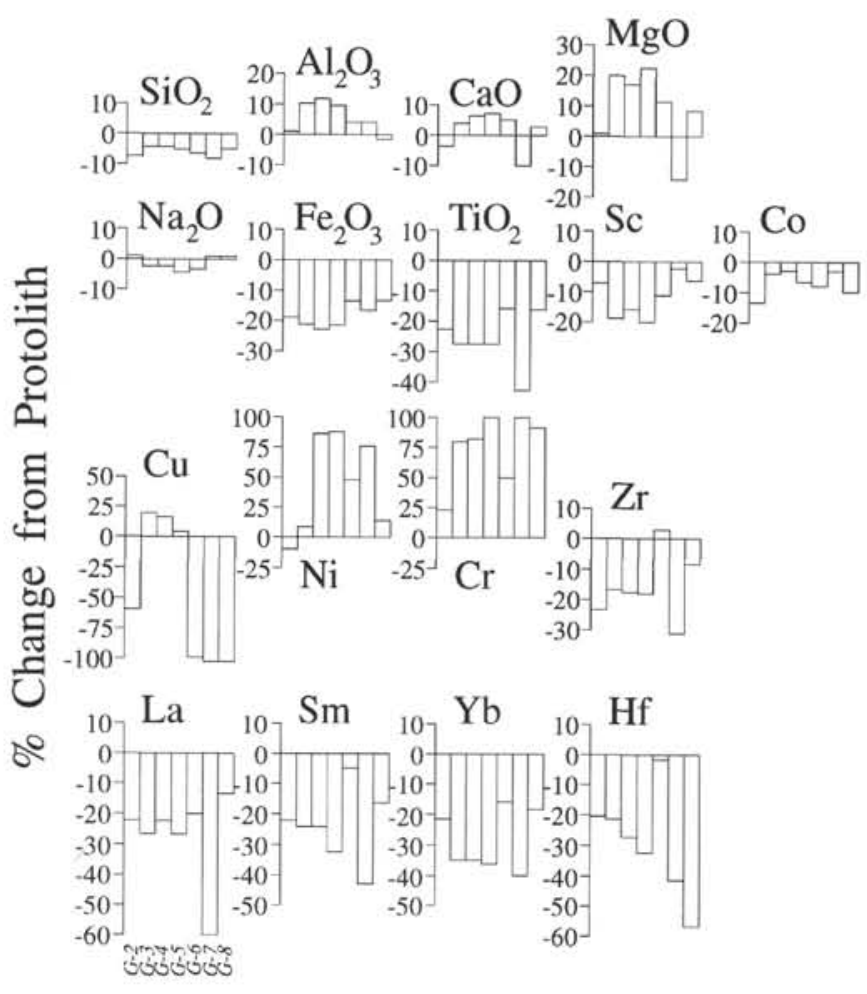

Figure 4. Gain-loss diagram of chemical components, using Gresens' method, in the sheeted dikes of Hole 504B, Leg 140. Reference sample used: G-1. The immobile element on which the calculations were based is $\mathrm{Zr}$. A volume factor $\left(f_{v}\right)$ of 1 was used.

mantle source. Using the approach developed for the trace elements, $\mathrm{Ti} / \mathrm{Zr}$ is plotted against $\mathrm{Yb} / \mathrm{Zr}$ in Figure 7 . Once again, all except the most altered samples define a linear array, and Samples G-6 and G-7 could be explained by Ti loss. Sample G-10 plots much too high, perhaps due to gain in $\mathrm{Ti}$, although source heterogeneity cannot be excluded.

\section{DISCUSSION}

\section{Platinum Group Elements (PGE)}

MORBs characteristically have steep PGE patterns, with very low concentrations. The origin of these patterns is not entirely clear, and our data may provide some new constraints.

During partial melting, Ir is likely to partition into the residual mafic silicates; Naldrett and Barnes (1986) have empirically estimated a partition coefficient of 10 . Pt, on the other hand, is largely incompatible, and, estimating a partition coefficient of say 0.1 , it is possible to calculate that the $\mathrm{Pt} / \mathrm{Ir}$ ratios in our samples could be derived by reasonable degrees of melting of about $10 \%-30 \%$. The absolute concentrations would be much too high, but they could be lowered without appreciably changing the $\mathrm{Pt} / \mathrm{Ir}$ ratio if a small amount of sulfide were to segregate during ascent (Naldrett and Barnes, 1986; Hamlyn et al., 1985).

However, this model does not account for the substantial enrichment of Au over Pt seen in our data. Even if the Au partition coefficient is zero, this enrichment would require Pt partition coefficients to be at least 1. Furthermore, no amount of juggling of Pt coefficients will solve a more fundamental problem - that of the $\mathrm{Au} / \mathrm{Ir}$ ratio. Ignoring G-5, where Ir is at the detection limit, Au/Ir ratios in our samples range from about 200 to 1000 (mantle normalized). The results of melting calculations in Table 4 show that the observed $\mathrm{Au} / \mathrm{Ir}$ ratios could only be achieved by melting in the range of $1 \%-5 \%$, much less than is generally accepted. Alternatively, normal degrees of melting could be approached only if the Ir partition coefficient were at least 50 .

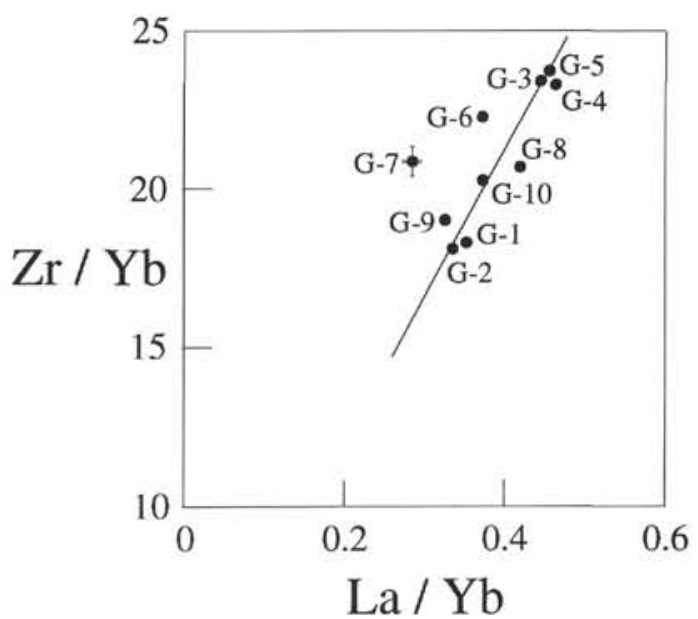

Figure $5 . \mathrm{Zr} / \mathrm{Yb}-\mathrm{La} / \mathrm{Yb}$ plot to determine the mobility of $\mathrm{La}$ in the sheeted dikes, Hole 504B, Leg 140. Error bar for data points is shown on Sample G-7.

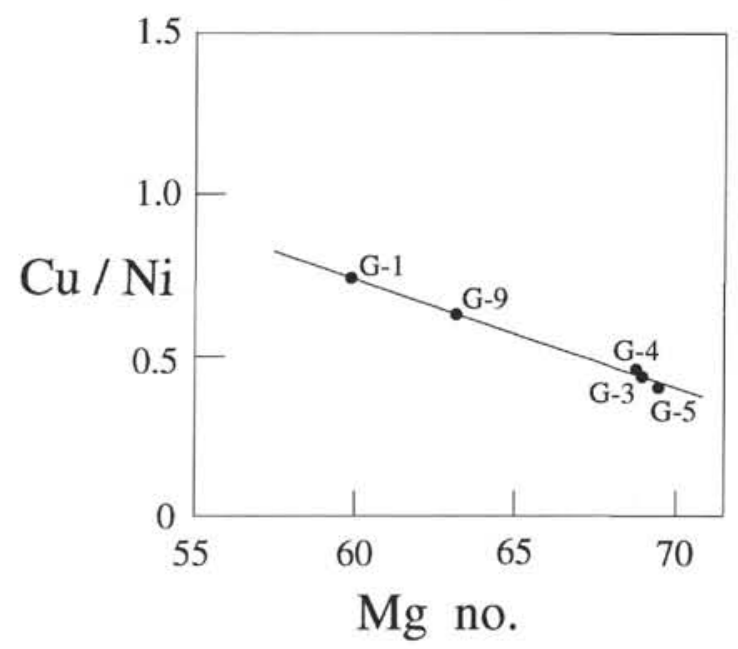

Figure 6. Cu/Ni-Mg number plot of unaltered dikes to calculate gain/loss of Cu during alteration, Hole 504B, Leg 140.

As both of these alternatives are unlikely, it is more plausible to suggest that the unusual PGE patterns of MORBs are, at least in part, inherited from their mantle source. It is unlikely that our Au concentrations have been raised by alteration. Sample G-2, which is significantly altered, shows no difference in Au concentration, and on the mantle-normalized plot, Au lies on a reasonable projection of Ir-Pt.

\section{Problems in Calculating Element Mobility}

We have demonstrated some of the problems encountered when estimating the mobility of various components during the hydrother$\mathrm{mal} /$ metasomatic alteration of a recent sheeted dike complex at the depth of $2 \mathrm{~km}$. We suggest that the original chemical heterogeneity and variable degrees of fractionation in the dikes make conventional mass balance calculations meaningless, unless the appropriate precursor of the altered rock can be identified. Thus an alternative approach that attempts to make allowance for these effects has been developed. The results, based on this approach, indicate the mobility of some elements during hydrothermal alteration. Significant decreases in $\mathrm{Cu}$ and $\mathrm{Zn}$ and some decreases in $\mathrm{La}$ and perhaps $\mathrm{Ti}$ are apparent in Figures 5 and 6 , although a quantitative estimation of these losses is not possible due to the lack of an equivalent unaltered parent.

The heterogeneous nature of the dikes in Hole 504B is comparable to the sheeted dikes of the Troodos ophiolite complex in Cyprus. 
Table 3. Calculated losses in $\mathrm{Cu}$ and $\mathrm{Zn}$, Legs 137/140.

\begin{tabular}{|c|c|c|c|c|c|c|}
\hline Core, section: & $194 \mathrm{R}-1$ & $205 \mathrm{R}-1$ & $214 R-1$ & $229 \mathrm{R}-1$ & $173 \mathrm{R}-1$ & $236 \mathrm{R}-1$ \\
\hline Interval $(\mathrm{cm})$ : & $91-93$ & $18-20$ & $21-22$ & $54-56$ & $24-27$ & $76-79$ \\
\hline Depth (mbsf): & 1681.3 & 1757.3 & 1818.9 & 1944 & 1571 & 1981.5 \\
\hline Sample number: & G-2 & G-6 & G-7 & G-8 & G-9 & G-10 \\
\hline Mg no. & 64.5 & 65.1 & 67.0 & 64.7 & 63.1 & 68.1 \\
\hline $\mathrm{Cu} / \mathrm{Ni}$ & 0.59 & 0.57 & 0.50 & 0.58 & 0.68 & 0.47 \\
\hline $\mathrm{Ni}$ & 80 & 120 & 156 & 99 & 91 & 123 \\
\hline Cu calc. & 47 & 68 & 78 & 57 & 0 & 58 \\
\hline Cu obs. & 28 & 4 & $<2$ & $<2$ & 0 & 20 \\
\hline $\mathrm{Cu}$ loss \% & 40 & 94 & 100 & 100 & 0 & 66 \\
\hline $\mathrm{Zn}$ loss & 30 & 0 & 44 & 51 & 51 & 62 \\
\hline
\end{tabular}

Table 4. Melting calculations to derive $\mathrm{Au} / \mathrm{Ir}$ ratios in the range of 200 1000, Leg 140.

\begin{tabular}{cccr}
\hline$\%$ melt & Ir & Au & Au/lr \\
\hline & $\mathrm{D}=10$ & $\mathrm{D}=0$ & \\
$10 \%$ & 0.11 & 10 & 91 \\
$5 \%$ & 0.10 & 20 & 200 \\
$1 \%$ & 0.10 & 100 & 1000 \\
& & & \\
\hline & $\mathrm{D}=50$ & $\mathrm{D}=0$ & \\
$20 \%$ & 0.02 & 5 & 250 \\
$10 \%$ & 0.02 & 10 & 500 \\
$5 \%$ & 0.02 & 20 & 1000 \\
\hline
\end{tabular}

Note: $\mathrm{D}=$ partition coefficient

Baragar et al. (1989) suggested that the magma for the Troodos dikes was derived from more than one magma chamber and that it fractionated to different degrees, giving the sheeted dikes a "mosaic composition." They concluded that although most of the dikes have been extensively altered to actinolite, minor chlorite, and epidote, metamorphic recrystallization was not accompanied by significant chemical changes. Apart from the loss of $\mathrm{CaO}$ and the addition of $\mathrm{K}_{2} \mathrm{O}$, most elements remained immobile (Baragar et al., 1989). Loss of $\mathrm{CaO}$ and gain in $\mathrm{K}_{2} \mathrm{O}$ has not been observed in the altered rocks reported here ( $\mathrm{CaO}$ is constant at $13-14 \mathrm{wt} \%$ and $\mathrm{K}_{2} \mathrm{O}$ is a very low $<0.1 \mathrm{wt} \%$ ); in addition, a significant loss in $\mathrm{Cu}, \mathrm{Zn}$, and $\mathrm{Ti}$ and some loss in $\mathrm{La}$ and $\mathrm{MgO}$ were observed in the lowermost part of Hole 504B. Otherwise, the results of Baragar et al. (1989) are broadly comparable to results obtained in this study. It is apparent from our study that a hydrothermal system penetrating the oceanic crust to the depth of $2 \mathrm{~km}$ is capable of leaching significant amounts of $\mathrm{Cu}, \mathrm{Zn}$, and some La during seawater/rock interaction from the dikes. Significant loss of $\mathrm{Cu}$ and $\mathrm{Zn}$ in basalts during seawater/rock interaction is consistent with models of volcanogenic massive sulfide deposits where $\mathrm{Cu}$ and $\mathrm{Zn}$ are leached from the oceanic crust at depth (at $\sim 250^{\circ}-350^{\circ} \mathrm{C}$ ) and deposited on the seafloor near the seawater/basalt interface.

Because the dikes in Hole 504B represent part of an in-situ ophiolite complex, our systematic approach is particularly useful for comparison to alteration studies of ancient ophiolite complexes on land, where most of the primary minerals have been destroyed by a metamorphic overprint.

The following guidelines may be useful when estimating element mobility during seawater/dike interaction in petrologically and geochemically heterogeneous rocks:

1. Cogenetic rocks from the same magmatic suite that underwent similar degree of fractionation should have comparable $\mathrm{Mg}$ numbers and $\mathrm{Zr}$ contents and plot on a single point on $\mathrm{Z} \mathrm{Zr} / \mathrm{Yb}-\mathrm{La} / \mathrm{Yb}$ diagram.

2. The dispersion on the line generated by $\mathrm{Zr} / \mathrm{Yb}-\mathrm{La} / \mathrm{Yb}$ ratios on the above diagram suggests tapping of a variably depleted mantle source. Deviation from the line indicates the mobility (gain or loss) of $\mathrm{La}$ (or other REE) during alteration.

\section{SUMMARY}

1. The low concentrations of PGE in the sheeted dike complex, Hole 504B, are typical of PGE of MORBs on the global scale

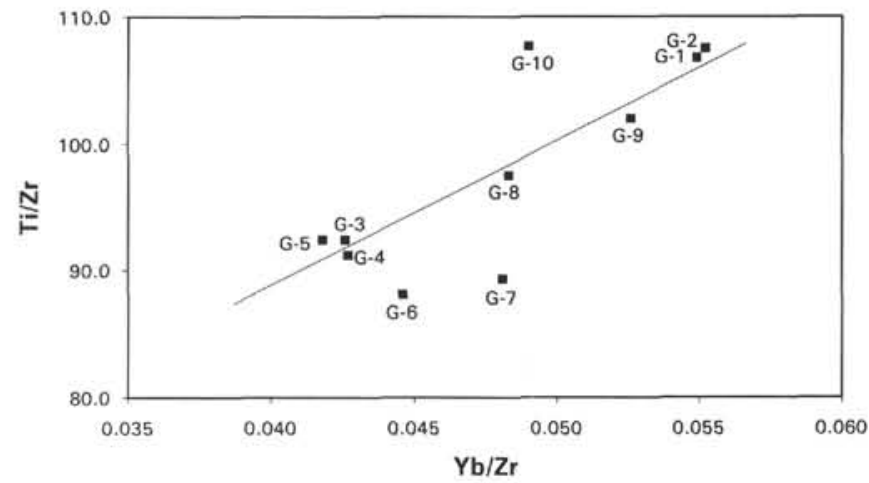

Figure 7. $\mathrm{Ti} / \mathrm{Zr}-\mathrm{Yb} / \mathrm{Zr}$ plot to determine gain/loss of Ti during alteration of the dikes, Hole 504B, Leg 140.

(Hertogen et al., 1980; Crocket, 1990). It is suggested that the unusual PGE patterns of MORBs are, at least in part, inherited from their mantle source. The Au concentrations in the dikes are remarkably constant, suggesting that Au was not mobilized during alteration.

2 . In the chemically heterogeneous dikes, conventional mass balance calculations are unsuitable for determining major and trace element mobility during hydrothermal alteration. Different magma sources and different degrees of fractionation make it difficult to find a suitable reference rock for the calculations. We suggest the use of incompatible element ratios to obtain qualitative estimation of gains and losses of various components during alteration.

3. Using the above method, our results suggest that geochemical changes that accompanied the hydrothermal/metasomatic evolution of the sheeted dike complex include significant loss in $\mathrm{Cu}, \mathrm{Zn}$, and $\mathrm{Ti}$ and some loss in $\mathrm{La}$.

\section{ACKNOWLEDGMENTS}

We are grateful to Dr. Mohammad Asif, Department of Geology, University of Toronto, for his help in determination of the PGE. Many thanks to Dr. Gerardo J. Iturrino for density determinations on the eight core samples during Leg 140 and to Subash Shanbhag for his skillful drafting of the diagrams. The helpful comments of Drs. J. Allan, S.-J. Barnes, and H. Dick on the first draft of this paper are gratefully acknowledged. E.S. thanks the Canadian Secretariat of ODP for the opportunity to participate in Leg 140.

\section{REFERENCES}

Allan, J.F., and Gorton, M.P., 1992. Geochemistry of igneous rocks from Legs 127 and 128, Sea of Japan. In Tamaki, K., Suyehiro, K., Allan, J., McWilliams, M., et al., Proc. ODP, Sci. Results, 127/128, Pt. 2: College Station, TX (Ocean Drilling Program), 905-929.

Alt, J.C., Anderson, T.F., Bonnell, L., and Muehlenbachs, K., 1989. Mineralogy, chemistry, and stable isotopic compositions of hydrothermally altered sheeted dikes: ODP Hole 504B, Leg 111. In Becker, K., Sakai, H., et al., Proc. ODP, Sci. Results, 111: College Station, TX (Ocean Drilling Program), 27-40.

Alt, J.C., and Emmermann, R., 1985. Geochemistry of hydrothermally altered basalts: Deep Sea Drilling Project Hole 504B. In Anderson, R.N., Honnorez, J., Becker, K., et al., Init. Repts. DSDP, 83: Washington (U.S. Govt. Printing Office), 249-262.

Alt, J.C., Honnorez, J., Laverne, C., and Emmermann, R., 1986. Hydrothermal alteration of a $1 \mathrm{~km}$ section through the upper oceanic crust, Deep Sea Drilling Project Hole 504B: mineralogy, chemistry, and evolution of seawater-basalt interactions. J. Geophys. Res., 91:10309-10335.

Asif, M., and Parry, S.J., 1989. Elimination of reagent blank problems in fire assay preconcentration of the platinum group elements and gold with

\footnotetext{
* Abbreviations for names of organizations and publications in ODP reference lists follow the style given in Chemical Abstracts Service Source Index (published by American Chemical Society).
} 
nickel sulphide bead weighing less than one gram. Analyst (London), 114:1057-1059.

Autio, L.K., and Rhodes, J.M., 1983. Costa Rica Rift Zone basalts: geochemi$\mathrm{cal}$ and experimental data from a possible example of multistage melting. In Cann, J.R., Langseth, M.G., Honnorez, J., Von Herzen, R.P., White, S.M., et al., Init. Repts. DSDP, 69: Washington (U.S. Govt. Printing Office), $729-745$.

Autio, L.K., Sparks, J.W., and Rhodes, J.M., 1989. Geochemistry of Leg 111 basalts: intrusive feeders for highly depleted pillows and flows. In Becker, K., Sakai, H., et al., Proc. ODP, Sci. Results, 111: College Station, TX (Ocean Drilling Program), 3-16.

Baragar, W.R.A., Lambert, M.B., Baglow, N., and Gibson, I.L., 1989. Sheeted dikes from CY-4 and surface sections: Troodos Ophiolite. In Gibson, I.L., Malpas, J., Robinson, P.T., and Xenophontos, C. (Eds.), Cyprus Crustal Study Project: Initial Report, Hole CY-4. Geol. Surv. Can., 69-106.

Barnes, S.-J., Boyd, R., Korneliussen, A., Nilsson, L.P., Often, M., Pedersen, R.B., and Robins, B., 1988. The use of mantle normalization and metal ratios in discriminating between the effects of partial melting, crystal fractionation, and sulphide segregation on platinum-group elements, gold, nickel and copper: examples from Norway. In Prichard, H.M., Potts, P.J., Bowles, J.F.W., and Cribb, S.J. (Eds.), Geo-Platinum 87: London (Elsevier), 113-141.

Crocket, J.H., 1990. Noble metals in seafloor hydrothermal mineralization from the Juan de Fuca and Mid-Atlantic ridges: a fractionation of gold from platinum metals in hydrothermal fluids. Can. Mineral., 28:639-648.

Dick, H.J.B., Erzinger, J., Stokking, L.B., et al., 1992. Proc. ODP, Init. Repts., 140: College Station, TX (Ocean Drilling Program).

Emmermann, R., 1985. Basement geochemistry, Hole 504B. In Anderson, R.N., Honnorez, J., Becker, K., et al., Init. Repts. DSDP, 83: Washington (U.S. Govt. Printing Office), 183-199.

Gresens, R.L., 1967. Composition-volume relationships of metasomatism. Chem. Geol., 2:47-65.

Hamlyn, P.R., Keays, R.R., Cameron, W.E., Crawford, A.J., and Waldron, H.M., 1985. Precious metals in magnesian low Ti lavas: implications for metallogenesis and sulfur saturation in primary magmas. Geochim. Cosmochim. Acta, 49:1797-1811.

Hertogen, J., Janssens, M.-J., and Palme, H., 1980. Trace elements in ocean ridge basalt glasses: implications for fractionations during mantle evolution and petrogenesis. Geochim. Cosmochim. Acta., 44:2125-2143.

Honnorez, J., Laverne, C., Hubberten, H.-W., Emmermann, R., and Muehlenbachs, K., 1983. Alteration processes in Layer 2 basalts from Deep Sea Drilling Project Hole 504B, Costa Rica Rift. In Cann, J.R., Langseth, M.G. Honnorez, J., Von Herzen, R.P., White, S.M., et al., Init. Repts. DSDP, 69: Washington (U.S. Govt. Printing Office), 509-546.

Hubberten, H.-W., Emmermann, R., and Puchelt, H., 1983. Geochemistry of basalts from Costa Rica Rift Sites 504 and 505 (Deep Sea Drilling Project Legs 69 and 70). In Cann, J.R., Langseth, M.G., Honnorez, J., Von Herzen, R.P., White, S.M., et al., Init. Repts. DSDP, 69: Washington (U.S. Govt. Printing Office), 791-803.

Humphris, S.E., and Thompson, G., 1978. Hydrothermal alteration of oceanic basalts by seawater. Geochim. Cosmochim. Acta, 42:107-125.

Marsh, N.G., Tarney, J., and Hendry, G.L., 1983. Trace element geochemistry of basalts from Hole 504B, Panama Basin, Deep Sea Drilling Project Legs 69 and 70. In Cann, J.R., Langseth, M.G., Honnorez, J., Von Herzen, R.P., White, S.M., et al., Init. Repts. DSDP, 69: Washington (U.S, Govt. Printing Office), 747-763.

Naldrett, A.J., and Barnes, S.-J., 1986. The behaviour of platinum group elements during fractional crystallization and partial melting with special references to the composition of magmatic sulfide ores. Fortschr. Mineral., 64:113-133.

Seyfried, W.E., and Bischoff, J.L., 1981. Experimental seawater-basalt interaction at $300^{\circ} \mathrm{C}, 500$ bars, chemical exchange, secondary mineral formation and implications for transport of heavy metals. Geochim. Cosmochim. Acta, 45:135-147.

Stix, J., and Gorton, M.P., 1992. Trace element analyses of ten U.S. Geological Standards by neutron activation analysis, using a low flux reactor. Geostand. Newsl., 8:17-23.

Tual, E., Jahn, B.M.. Bougault, H., and Joron, J.L., 1985. Geochemistry of basalts from Hole 504B, Leg 83, Costa Rica Rift. In Anderson, R.N., Honnorez, J., Becker, K., et al., Init. Repts. DSDP, 83: Washington (U.S. Govt. Printing Office), 201-214.

Date of initial receipt: 12 April 1993

Date of acceptance: 11 October 1994

Ms 137/140SR-012

\section{APPENDIX}

\section{Thin-section Descriptions, Leg 140}

Sample number: G-1 (193R-1; 0-3 cm)

Primary mineralogy: $47 \%$ plagioclase, $30 \%$ clinopyroxene, $5 \%$ titanomagnetite.

Secondary mineralogy: talc, deweylite (mixture of serpentine and stevensite), magnetite, pyrite ( $10 \%$ ) replaces olivine. Actinolite ( $7 \%$ ) replaces clinopyroxene, and titanite $(1 \%)$ replaces titanomagnetite.

Sample number: G-2 (194R-1; 91-93 cm)

Primary mineralogy: $27 \%$ plagioclase, $10 \%$ clinopyroxene.

Secondary mineralogy: actinolite $(40 \%)$ replaces clinopyroxene, chlorite (15\%) replaces olivine and plagioclase, albite $(5 \%)$ replaces plagioclase, and titanite $(3 \%)$ replaces titanomagnetite.

Sample number: G-3 (199R-1; 78-80 cm)

Primary mineralogy: plagioclase $(55 \%)$, clinopyroxene $(38 \%)$, and titanomagnetite $(1 \%)$.

Secondary mineralogy: talc $(4 \%)$, chlorite $(2 \%)$, and magnetite (trace) replaces olivine. The rock consists of $10 \%$ phenocrysts (plagioclase, clinopyroxene, and altered olivine).

Sample number: G-4 (199R-1; 110-114 cm)

Primary mineralogy: plagioclase $(50 \%)$, clinopyroxene $(35 \%)$, and titanomagnetite $(1 \%)$.

Secondary mineralogy: actinolite $(8 \%)$ interstitial and replaces clinopyroxene, talc (3\%), chlorite ( $2 \%)$, and magnetite (trace) replaces olivine.

Sample number: G-5 (200R-2; 49-52 cm)

Primary mineralogy: plagioclase $(50 \%)$, clinopyroxene $(35 \%)$, and titanomagnetite $(2 \%)$.

Secondary minerals: actinolite $(8 \%)$ replaces clinopyroxene, and talc, deweylite $(3 \%)$, and magnetite (trace) replaces olivine. The rock consists of $5 \%$ phenocrysts of plagioclase and altered olivine.

Sample number: G-6 (205R-1; $18-20 \mathrm{~cm})$

Primary mineralogy: plagioclase (20\%) and clinopyroxene (5\%). Extensively altered rock.

Secondary mineralogy: actinolite $(50 \%)$ occurs in veins and replacement after clinopyroxene, albite $(20 \%)$ replaces plagioclase, and titanite $(5 \%)$ replaces titanomagnetite.

Sample number: G-7 (214R-1; 21-22 cm)

Primary mineralogy: plagioclase $(20 \%)$.

Secondary mineralogy: actinolite $(73 \%)$ occurs in patches and veins and also replaces clinopyroxene. Albite $(5 \%)$ and chlorite $(3 \%)$ partly replaces plagioclase, and titanite $(2 \%)$ replaces titanomagnetite.

\section{Sample number: G-8 (229R-1; 54-56 cm)}

Primary mineralogy: plagioclase phenocrysts $(5 \%)$ are set in a matrix of fine-grained plagioclase $(30 \%)$ and clinopyroxene $(5 \%)$.

Secondary mineralogy: actinolite $(50 \%)$ is interstitial to and replaces clinopyroxene, titanite $(5 \%)$ replaces titanomagnetite, and albite $(5 \%)$ partly replaces plagioclase.

Sample number: G-9 (173R-1; 24-27 cm)

Primary mineralogy: equigranular, zoned plagioclase (45\%), clinopyroxene $(38 \%)$, and titanomagnetite $(5 \%)$.

Secondary mineralogy: talc, chlorite, deweylite and magnetite $(5 \%)$ replaces olivine, and fine-grained actinolite $(3 \%)$ is interstitial to and partly replaces clinopyroxene.

Sample number: G-10 (236R-1; 76-79 cm)

Primary mineralogy: plagioclase (5\% phenocryst and $45 \%$ groundmass), clinopyroxene (25\%), and titanomagnetite (2\%).

Secondary mineralogy: actinolite $(10 \%)$ is interstitial to and partly replaces clinopyroxene, titanite $(1 \%)$ replaces titanomagnetite. Talc, chlorite, and magnetite $(2 \%)$ replaces olivine. 